\title{
Discurso de Posse do Professor Antonio Carlos de Araujo Cintra
}

Professor Dalmo de Abreu Dallari, Diretor da Faculdade de Direito.

Professora Ada Pellegrini Grinover, cujas formosas palavras bem refletem a grandeza e a generosidade de seu espírito.

Douta Congregação, que ora me acolhe com fidalguia inecedível.

Meus queridos alunos, de tantas gerações das Arcadas imortais.

Caros funcionários, cuja amável colaboração nunca me faltou.

Minhas senhoras e meus senhores:

Noutras circunstâncias, seria inescusável ousadia pretender falar-vos, pois não recebi o dom da eloqüência que adorna o verbo inspirado dos oradores desta manhã de primavera.

Hoje, porém, não me é dado calar.

Para mim, é um dia de plenitude e de festa, o coroamento de longo e prolongados esforços, de estudos, pesquisas, meditação e trabalho a que me dediquei, no correr de anos, com sempre renovado entusiasmo, estimulado pelo esplêndido convívio com a mocidade acadêmica e pelo constante apoio e conselho dos Mestres desta Casa. Por isso, quero partilhar com todos a alegria desta hora singular, agradecendo, profundamente, a cada um que me tenha ajudado na caminhada para que ela se tornasse possível.

Volto meus olhos para o futuro.

Assumindo o honroso cargo de Professor Titular de Direito Processual Civil da Faculdade de Direito do Largo de São Francisco, "alma matér", prometo consagrar a maior energia e a diligência de que for capaz ao desempenho da grata missão que lhe é inerente. Prometo prosseguir, com o mesmo ardor do 
noviciado, no cumprimento do ofício docente, com o fito maior de despertar a chana da consciência jurídica dos jovens estudantes, lançando em campo fértil a semente dos valores fundamentais do direito, que se alicerçam na transcendente dignidade da pessoa humana. Prometo lutar, na medida das minhas forças, pela continuidade das tradições da Velha Academia pois, plasmadas nos bancos escolares e nas cátedras, em torno dos ideais vivificantes de liberdade $\mathrm{e}$ de justiça, elas a mantêm sempre nova e atual.

Tudo farei para corresponder à confiança em mim depositada.

Muito obrigado.

PROF. ANTONIO CARLOS DE ARAÚJO CINTRA 